\title{
Key to the larval stages of common Odonata of Hindu Kush Himalaya, with short notes on habitats and ecology
}

\author{
Hasko Nesemann ${ }^{1}$, Ram Devi Tachamo Shah ${ }^{2} \&$ Deep Narayan Shah ${ }^{3}$ \\ ${ }^{1}$ Centre for Environmental Science, Central University of Bihar, BIT Campus, Patna, Bihar 800014, India \\ ${ }^{2}$ Hindu Kush Himalayan Benthological Society, Kausaltar, Nepal. P.O. Box: 20791, Sundhara, Kathmandu, Nepal \\ ${ }^{3}$ Senckenberg Research Institutes and Natural History Museums, Department of Limnology and Nature Conservation, \\ Clamecystrasse 12, D-63571, Gelnhausen, Germany. \\ Email: ${ }^{1}$ hnesemann2000@yahoo.co.in, ${ }^{2}$ ramdevishah@hkhbenso.org (corresponding author), ${ }^{3}$ Deep-Narayan.Shah@senckenberg.de
}

Date of publication (online): 26 September 2011 Date of publication (print): 26 September 2011 ISSN 0974-7907 (online) | 0974-7893 (print)

Editor: K.A. Subramanian

Manuscript details:

Ms \# 02759

Received 11 April 2011

Final received 22 July 2011

Finally accepted 11 August 2011

Citation: Nesemann, H., R.D.T. Shah \& D.N. Shah (2011). Key to the larval stages of common Odonata of Hindu Kush Himalaya, with short notes on habitats and ecology. Journal of Threatened Taxa 3(9): 2045-2060.

Copyright: (c) Hasko Nesemann, Ram Devi Tachamo Shah \& Deep Narayan Shah 2011. Creative Commons Attribution 3.0 Unported License. JoTT allows unrestricted use of this article in any medium for non-profit purposes, reproduction and distribution by providing adequate credit to the authors and the source of publication.

Author Details: Hasko Nesemann, Ram Dev Tachamo ShaH \& Deep Narayan Shah are aquatic ecologists. They are specialized in aquatic macroinvertebrates diversity with a keen interest in freshwater ecology, biogeography, conservation, and ecological water quality monitoring

Author Contribution: HN, RDTS and DNS conducted fieldworks and equally contributed in manuscript preparation. HN illustrated the specimens.

Acknowledgements: We want to thank Subodh Sharma (Aquatic Ecology Centre, Kathmandu University, Dhulikhel, Kavre, Nepal), Gopal Sharma (Zoological Survey of India, Gangetic Plains Regional Station, Patna, India), and R.K. Sinha (Centre for Environmental Science, Central University of Bihar, Patna, India) for their help in fieldwork

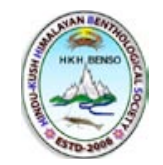

\section{(c) (7) (口)}

OPEN ACCESS | FREE DOWNLOAD
Abstract: The order Odonata is one of the most widely studied groups among insects from the oriental region. They colonize in both stagnant and running water bodies of wide water quality. Hitherto, the existing literature on the Odonata contained numerous publications with coloured figures of adults, helpful for identification. Identification key with figures on larval stages, using their coloration as distinguishing characters are largely missing. The current work attempts to provide an identification key to aquatic larvae of the most common families of Zygoptera, Anisoptera and Anisozygoptera with colour illustrations. The specimens were collected from Nepal and India (northern part). Each family is represented by several examples to demonstrate the range of morphological variability. This key helps determination of aquatic larvae Odonata up to family level without enormous efforts in field and laboratory.

Keywords: Aquatic insect, damselfly, dragonfly, ecology, identification key, India, Nepal.

\section{INTRODUCTION}

The modern order Odonata is highly diversified with $5,680-5,747$ (accepted) extant species, 864 (accepted) extant subspecies and approximately 600 fossil species (Xylander \& Günther 2003; Kalman et al. 2008; van Tol 2008). The highest species number is known from the Oriental region which has more than 1,000 species. From India, exactly 499 species were recorded until 2005 by Mitra and 463 species confirmed by Subramanian (2009). Among all the species and subspecies within this geographical limit, the figure or description is known only for 78 taxa (Mitra 2005). For Nepal the number of species and subspecies was previously 172 published by Vick (1989). Later Sharma (1998) listed 202 taxa and Kemp \& Butler (2001) added a new species for the country. In Bhutan, Mitra (2006) has published an actualized Odonata list with 31 taxa, to which the occurrence of Epiophlebia laidlawi around Thimpu can be added (Brockhaus \& Hartmann 2009).

The taxonomy and knowledge of odonates in the Indian subcontinent and in many other parts of the world is largely based on terrestrial adults. There has been an old tradition in publication of very high quality colour figures for each species since the 18th century (Malz \& Schröder 1979). In recent years all known Odonata species from the Japanese Archipelago were published by Okudaira et al. (2005) giving colour figures of both the larvae and the adults.

Mitra (2003) has provided an updated list of the regional species 
composition for the different ecoregions of the Indian subcontinent. It allows recognition of the local fauna and the possible presence of their aquatic larvae for the Himalayan region. In contrast, the distinction of aquatic odonates from the same territory is poorly known. Even the identification at the family level remains difficult for many Zygoptera (Superfamilies Coenagrionoidea, Lestoidea) and some Anisoptera (Libellulidae vs. Corduliidae).

The classification of the order Odonata at the family level is a matter of controversy/ discussion. The number of families recognized by different authors varies largely. The 15 families in St. Quentin \& Beier (1967), 27 families in Trueman \& Rowe (2001), 56 families in Xylander \& Günther (2003) demonstrate the different views. The present study follows the proposed system of Kalkman et al. (2008) with one addition.

The Odonata represents 7\% among a total of 76,000 freshwater insect species of the world (Balian et al. 2008). Many species have small distributional ranges, and are habitat specialists; including inhabitants of alpine mountain bogs, seepage areas in tropical rain forests, and waterfalls (Kalkman et al. 2008). Larvae are mostly aquatic and predatory in nature. They feed on small odonates, oligochaetes, chironomids, bettles, bugs, mayflies, molluscs, even tadpoles and small fishes, thus playing a major role in the aquatic ecosystem. The Odonata richness alone occupies a major component in freshwater macroinvertebrate assemblages. This aspect is clearly shown in Fig. 1 based on data sets of 250 macroinvertebrate samples from various studies (Shah 2007; Tachamo 2007; Nesemann 2009; Tachamo 2010).

The order Odonata is an ideal model taxon for the investigation of the impact of environmental warming and climate change due to its tropical evolutionary history and adaptations to temperate climates (Hassall \& Thompson 2008). Its assemblages are also considered as surrogates for the insect community structure in water bodies, being capable of indicating changes in the biological integrity of these ecosystems (Silva et al. 2010). This can be proven from the newly developed HKHbios scoring (Ofenböck et al. 2010) list for the Hindu Kush Himalayan river system (Fig. 2). The Odonata at family level alone occupy about $11 \%$ of the scoring list with tolerance scores ranging from 5 to 10 .

The objective of the present study is to fill the gap in the knowledge of the odonata larvae and to provide a pictorial catalogue to help in their identification. Here 31 examples from recent collections are presented to

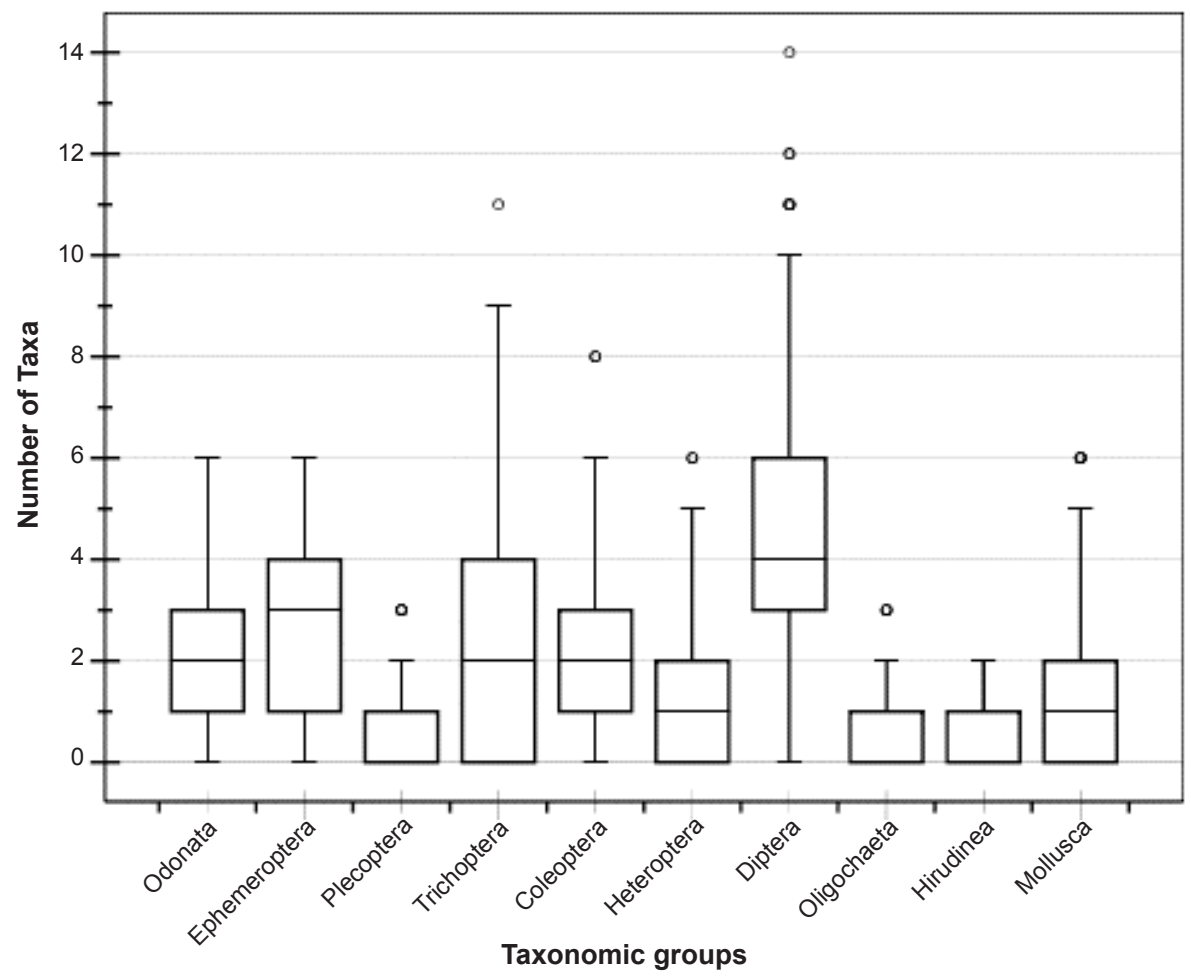

Figure 1. Number of taxa in different taxonomic groups based on 250 macroinvertebrate samples data. Whiskor and Box plots: $\square$ indicates $25-75^{\text {th }}$ percentile range; - indicates median; 0 indicates outliers (both graphs) 


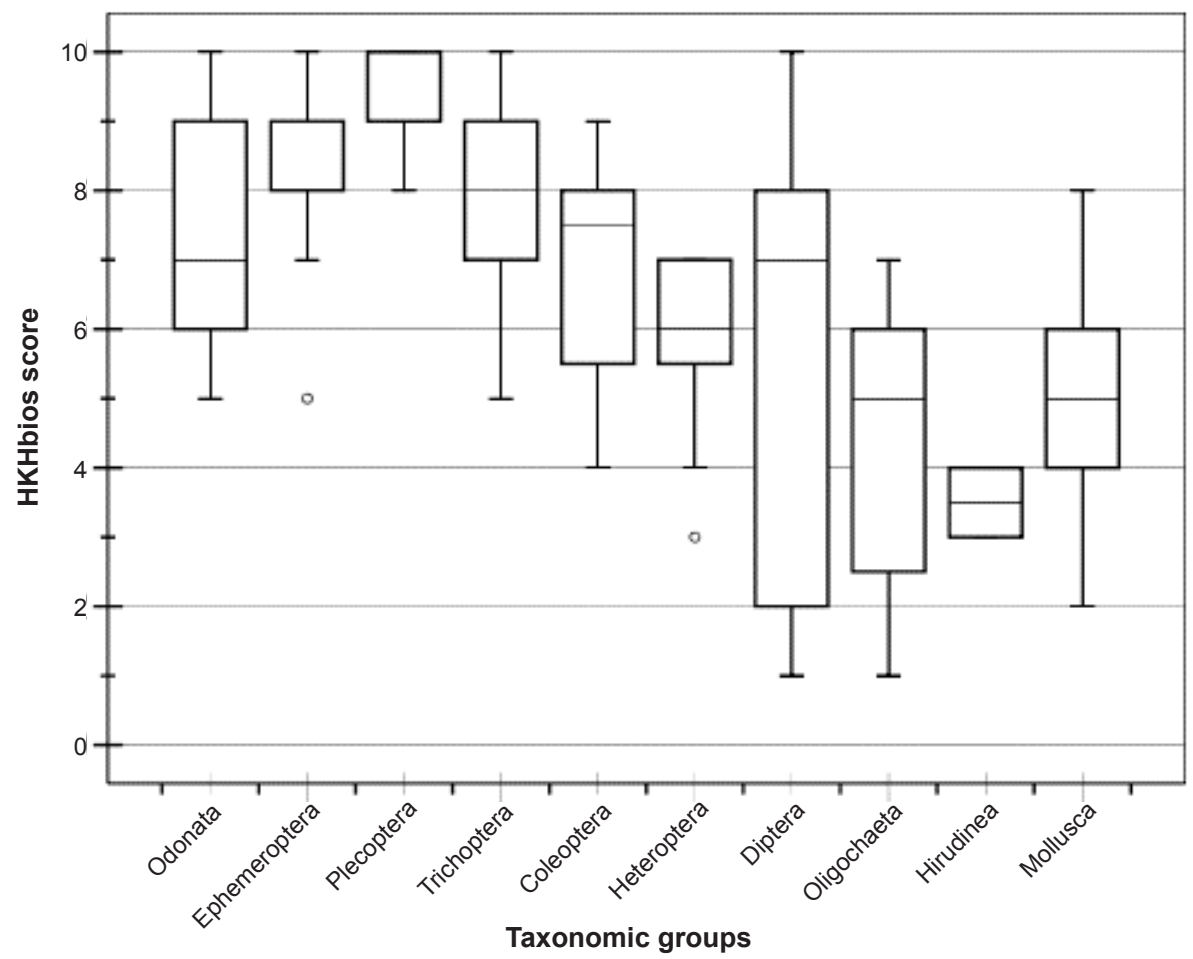

Figure 2. Taxa Tolerance scores of macroinvertebrates in HKHbios Scoring list (Ofenböck et al. 2010) for different taxonomic groups. HKHbios list consists of 139 families from different taxonomic groups for Hindu Kush Himalaya.

give their morphological characters as well as live colour. Colour was studied in living materials.

\section{Identification characters of odonata larvae}

Srivastava (1990) highlighted that the aquatic phase of the life cycle comprises eggs, pro-larval and larval stages, and 70-95\% of the whole life span is passed in water. Larvae undergo approximately 10-20 molts (mostly 11-14), over a period of three months (e.g. some Libellulidae) and about 6-10 years (e.g. Epiophlebiidae) depending on the species. One characteristic shared by all Odonata larvae is the conspicuous grasping labium (mask) (Fig. $3 \mathrm{a}-\mathrm{c}$ ), used for capturing the prey. At rest stage, the labium is held folded underneath the head. During prey-capture, the labium is shot rapidly forward and the prey is grasped with paired hand-like lateral lobes (palps). Form, size and number of mental setae can be used for family or even genus identification but requires a microscope. Even from the above characters and with mask retracted, identification of larvae to suborder and family is very easy, based on several other features. These are namely the apices of abdomen, number and form of caudal gills, presence of abdominal gills, form, size and number of segments of antennae, presence of teeth along the anterior margin of the lateral lobes (palps) of labium (mask) and anal

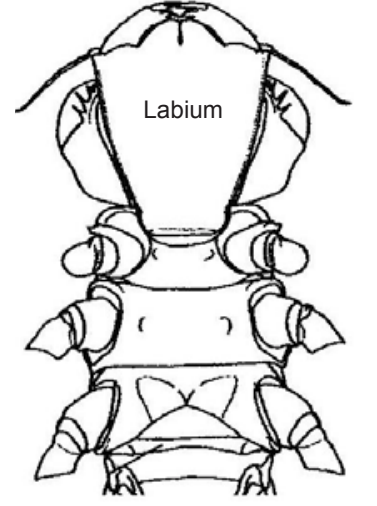

a

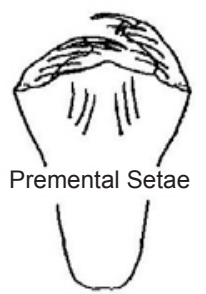

b

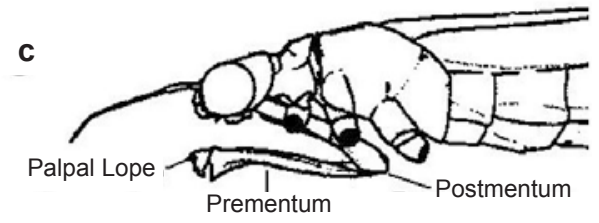

Figure 3 a-c. Head with labium of Damselfly larvae $\mathbf{a}$ - ventral view of Euphaeidae; $\mathbf{b}$ - dorsal view of labium of Coenagrionidae showing the premental setae; c - lateral view showing the resting position of labium.

pyramid with length relationship of epiproct, paraprocts and cerci (Fig. 4 a-b).

The identification of larvae (nymphs) even to genus, is often difficult because of the fact that morphological differences are so slight (Pennak 1978, 

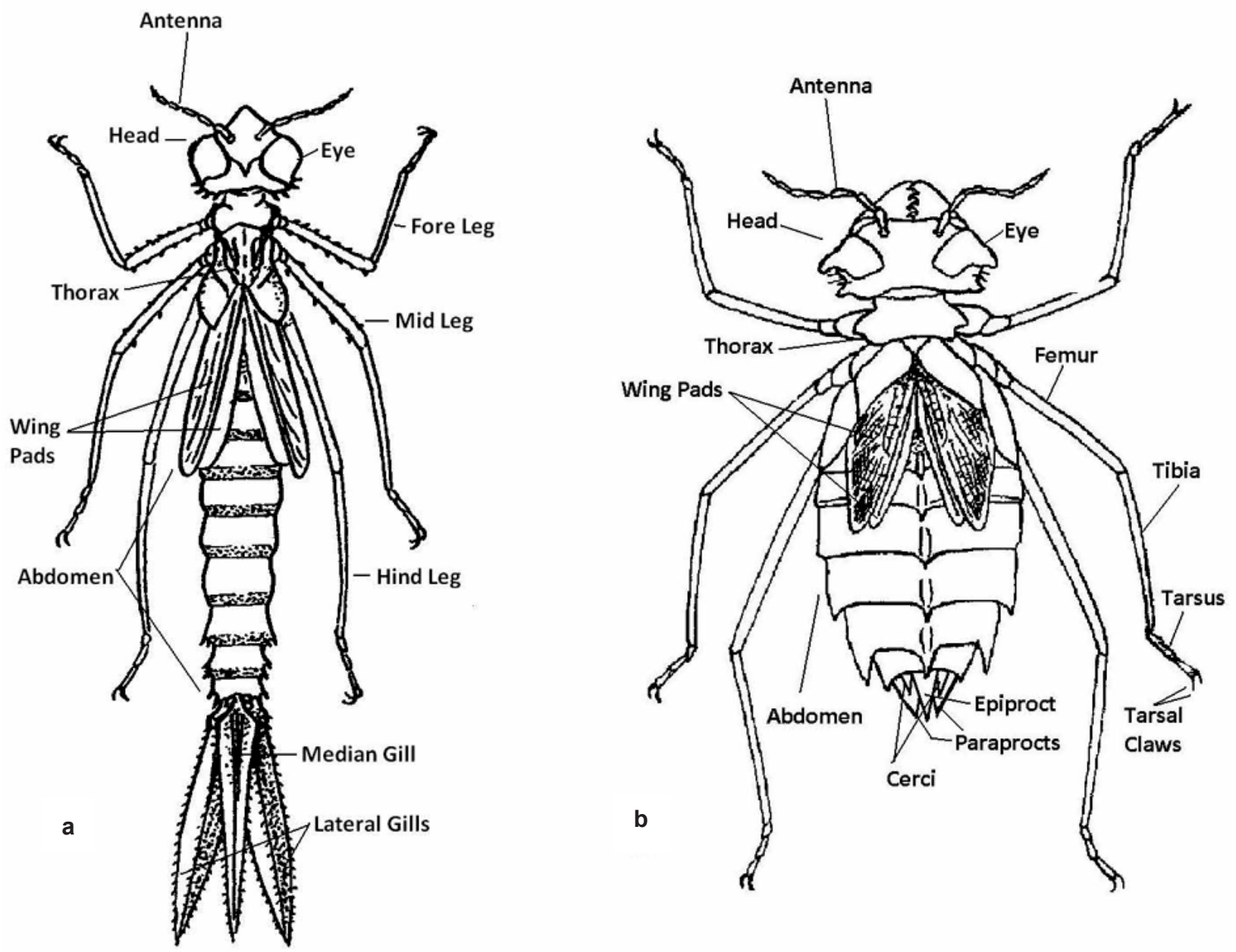

Figure 4 a-b. Odonata Morphology [figs. modified from Fraser 1919b (pl. XXXII fig. 3, pl. XXXVI, fig. 3)].

a - dorsal view of Damselfly larva Protoneuridae: Disparoneura spec.; b - dorsal view of Dragonfly larva Libellulidae: Tramea spec.

p. 557). Therefore, keys must be used with great care.

The identification of the collected and figured specimens was mainly based on descriptions given for the Odonata fauna of Japan (Kawai 2005; Okudaira et al. 2005), Malaysia (Yule \& Hoi Sen 2004), and a few available publications from the western Himalayan region (Kumar 1973; Mitra 2005). The identification result reached in the present study remains mostly at family level. Only in a few cases the genus or species level could be reached.

\section{MATERIALS AND METHODS}

\section{Study area}

The study was carried out in various parts of Nepal and the northern part of India (Fig. 5) between 2005 and 2009. The climate in the region varies from humid sub-tropical to temperate with hot summers from March to early June, the monsoon season from mid-June to September and winter from November to February. There is a dominance of monsoon rainfall pattern with maximum precipitation in the summer. The region is one of the most fertile and densely populated regions of the world.

All the illustrated specimens are with the authors' personal collection.

\section{Illustrated catalogue Zygoptera: Chlorocyphidae}

The medium-sized larvae (Fig. 6) have two forceps-like caudal gills which are triangular in cross section. They inhabit unpolluted, fast running streams and rivers (Fraser 1919a; Kumar \& Prasad 1977). 


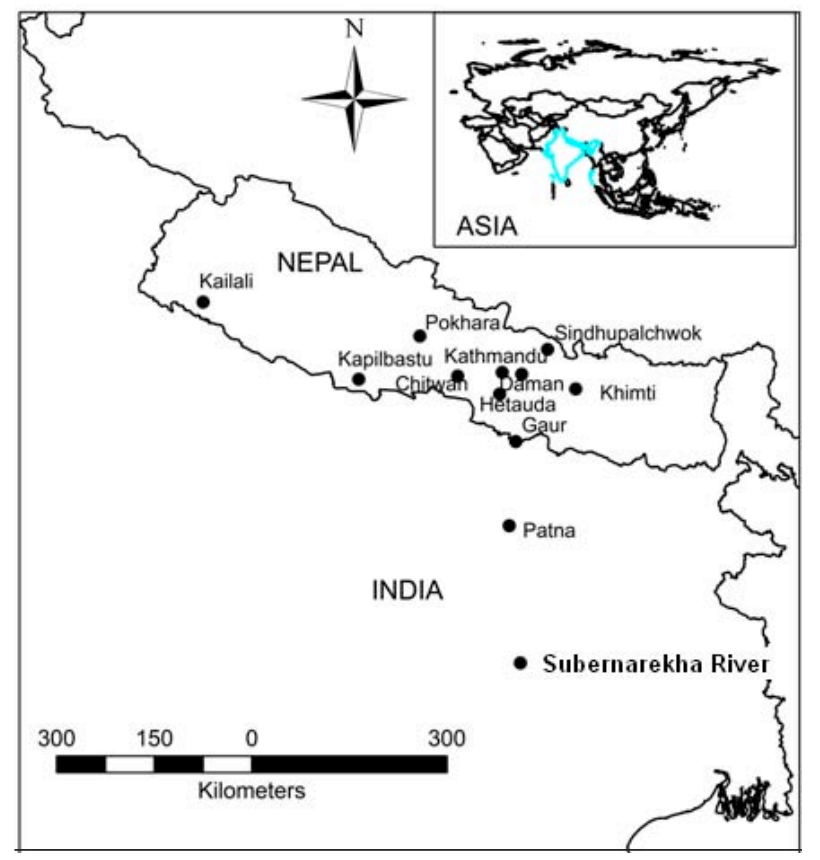

Figure 5. Major study sites in Nepal and India.

Chlorocyphidae occur from tropical Africa to Australia with the highest diversity in the Oriental region (Kalkman et al. 2008). The family is represented with 21 species in India (Subramanian 2009) and five have been recorded from Nepal (Sharma 1998) based on adults.

\section{Euphaeidae}

The larvae (Image $1 \mathrm{a}-\mathrm{b}$ ) are medium-sized to

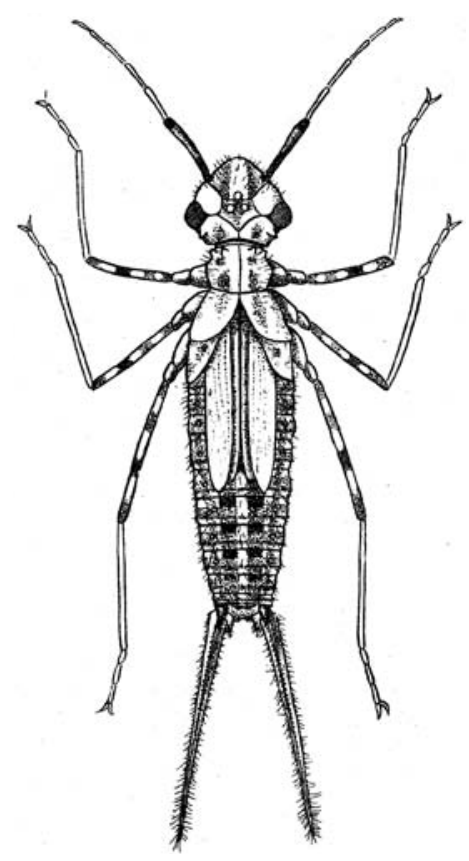

Figure 6.

Chlorocyphidae [fig. taken from Fraser 1919a (fig. No. XXIII), Libellago sp. (syn. Micromerus), length unknown]

large and robust with stonefly-like, flattened body form. They have three very large caudal gills that are saccoid. In addition, there are filamentous gills on the underside of abdominal segments II-VIII that are light grey-blue and un-pigmented (Image 1b). These characters allow easy identification of the family in the field.

Euphaeidae (and some related families) are distributed from the Mediterranean in the west to Japan
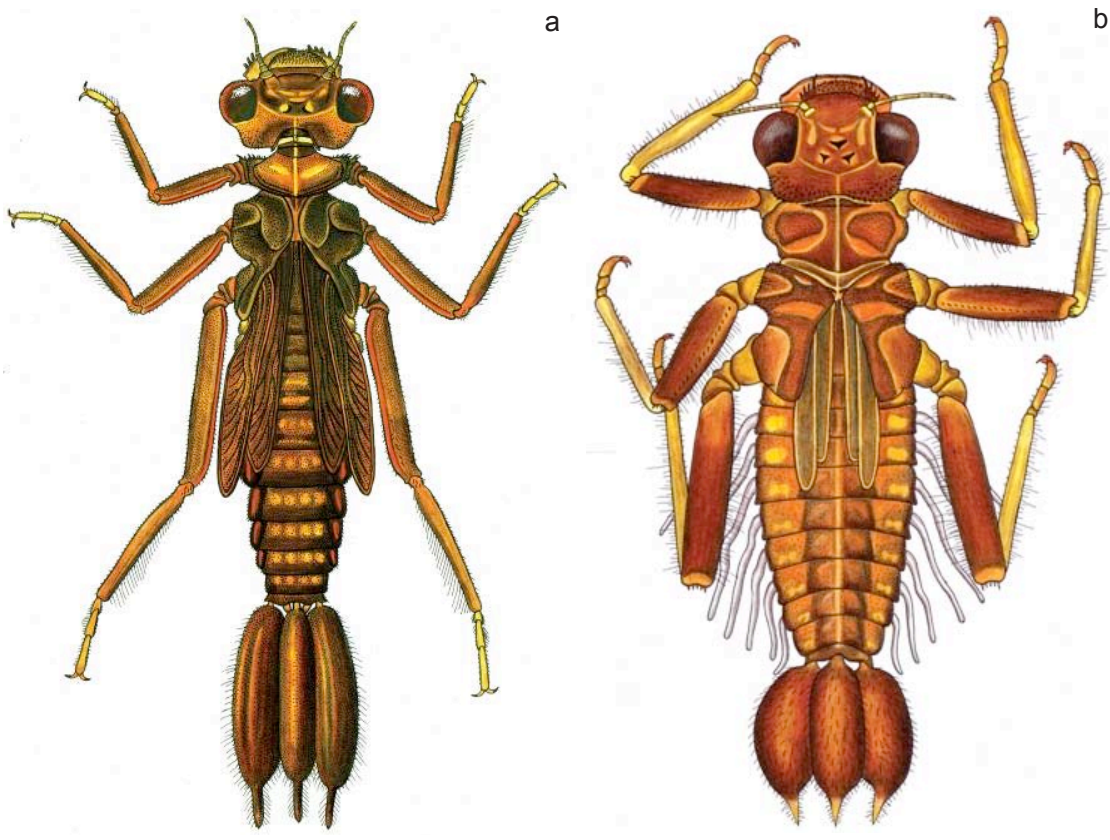

Image 1 a-b. Euphaeidae - Habitat: a - Khimti Khola, central Nepal, length 29.3mm; b - Yangi Khola, Pokhara, western Nepal. Length $21 \mathrm{~mm}$. 
in the east. These pollution-sensitive larvae are highly specialized on lotic microhabitats. They are locally common in fast running streams and smaller rivers of the Himalayan middle mountains. They prefer unpolluted waters with low organic load. Usually they are found on the underside of large stones in high water current of riffles and rapids together with large stoneflies of the family Perlidae. Earlier Euphaeidae were often united with other similar forms as families Polythoridae and Epallagidae (Xylander \& Günther 2003).

\section{Calopterygidae}

The family is also known as broad-winged Damselflies (Image 2). The larvae of the family has a shorter middle gill than lateral gills that are triangular in cross section without visible veins. Prementum is diamond shaped with deep median cleft. Palpal lobes are deprived of setae. First segment of antenna is longer than or equal to the combined length of the remaining antennal segments. The body size ranges between 30-40 mm.

The family has cosmopolitan distribution and contains 171 species worldwide. They are most often found at the edge of streams with slow flowing water. In the study area, they were clinging to root masses and overhung on twigs.

\section{Synlestidae}

The caudal gills of Synlestidae (Image 3) are short, broad and leaf like rounded, with oval apices and a smaller median lobe. Prementum or palps do not hold any setae. The mentum is deeply cleft. The palpal lobes have a long moveable hook and two robust spines. The adults are large, metallic green or bronzeblack damselflies inhabiting in forested streams. A distinct 'breaking joint' or area of weakness occurs at the base of each caudal gill. In our study, Synlestidae occurred in pristine rocky mountain streams at an elevation of $1600 \mathrm{~m}$.

\section{Amphipterygidae (including: Philogangidae)}

The deeply pigmented aquatic larvae (Image 4) are typical running water species which have a flattened body and bear long 7-segmented antennae. They may be larger than other damselflies and have a stonefly-like appearance. The palpal lobes of the labium have three spines and one movable hook. Their long gills are of

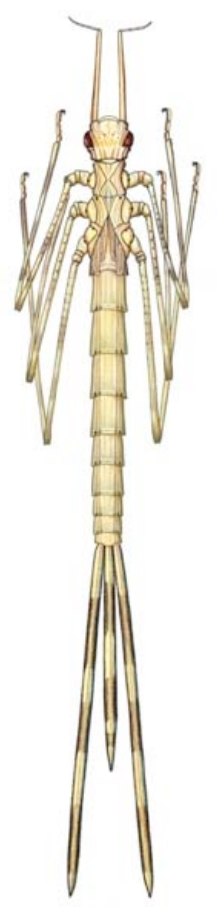

Image 2. Calopterygidae Habitat: Sano Khahare Khola, Maghi gau, central Nepal. Length $38 \mathrm{~mm}$.

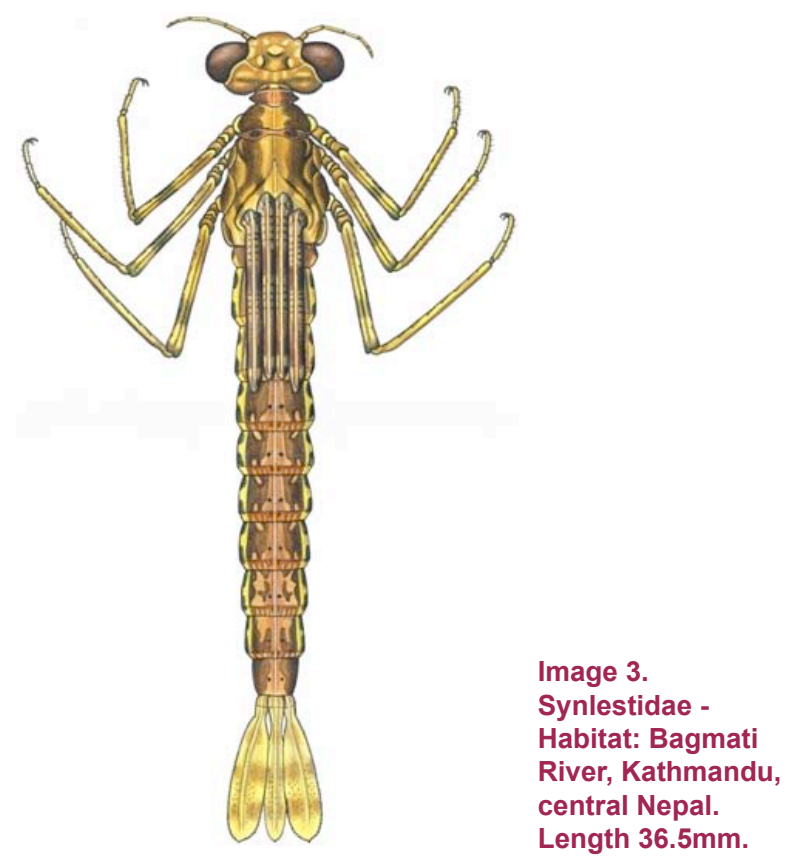

saccoid type. They are rare in the Himalayan region with a few scattered records from Nepal (Kemp \& Butler 2001) and northeastern India from Darjeeling to Assam and Meghalaya (Prasad \& Varshney 1995).

This family includes around 10-12 species of 4-5 genera in the tropical and oriental region. They share generally plesiomorhic characters and might be an ancient relict line within the Zygoptera (Dudgeon 1999; Kalkman 


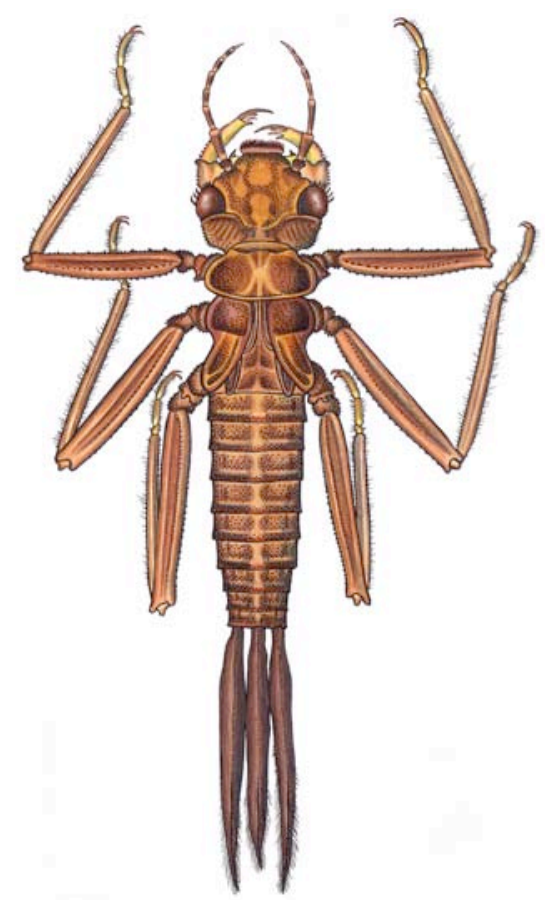

Image 4. Amphipterygidae Habitat: Poyang, China. length 24.5mm.

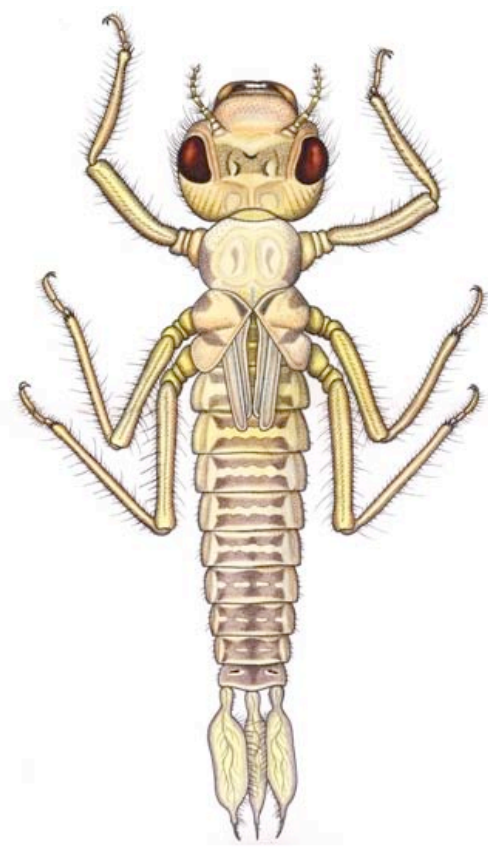

Image 5.

Platystictidae Habitat: Jakeshwori Khola, Melamchi, central Nepal. Length $15 \mathrm{~mm}$

et al. 2008, 2010). The genus Philoganga is often separated as subfamily or family (Subramanian 2009).

\section{Platystictidae}

The larvae of the Platystictidae family (Image 5) possess more or less saccoid gills as in Euphaeidae, but do not bear any abdominal gills. The palpal lobes of the labium consist one spine and one movable hook. The colour pattern of the body is pale and somewhat

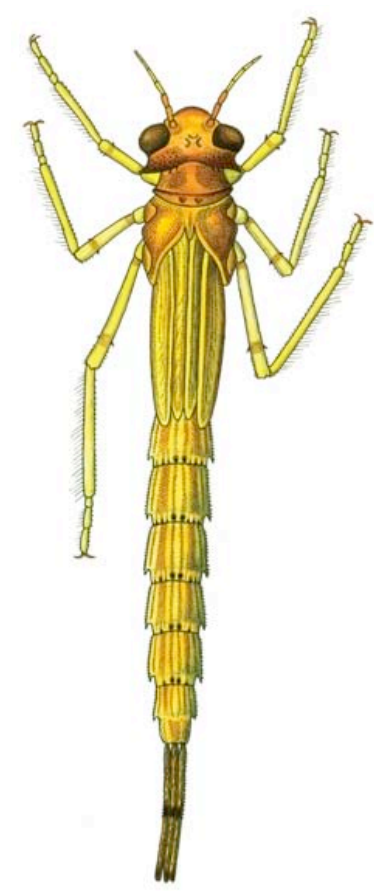

Image 6. Protoneuridae Habitat: Ghate Khola (Inlet of fishpond), Hetauda, central Nepal. Length: $13 \mathrm{~mm}$. spindly with large bulbous eyes.

The Platystictidae are widespread in South Asia to Southeast Asia (New Guinea) and are also known from central America and the northern part of South America. The larvae are found in small forested streams. Around 191-213 species are known worldwide (Kalkman et al. 2008; van Tol 2008).

\section{Protoneuridae}

The larvae of this family (Image 6) have twosegmented leaf-like caudal gills of similar shape and length. The gills are clearly divided into a thickened dark proximal portion and a thin, paler distal part. The anterolateral margins of the labial mentum are fringed with tiny teeth. One premental seta is situated on either side of the midline of the mentum. There are three setae on the palpal lobes. This family has delicate aquatic larvae with flattened bodies and relatively long antennae; the long, slender legs are fringed with setae. The posterior margin of the head forms two lateral horn-like extensions, whereas it is smoothly rounded in Coenagrionidae.

Protoneuridae have a wide distribution in tropical and subtropical zones but they are insufficiently known and not generally recognized as family by traditional odonatology. Protoneuridae inhabit in a narrow range of slowly running and stagnant waters. The most abundant fauna is found in wetlands and lentic zones 


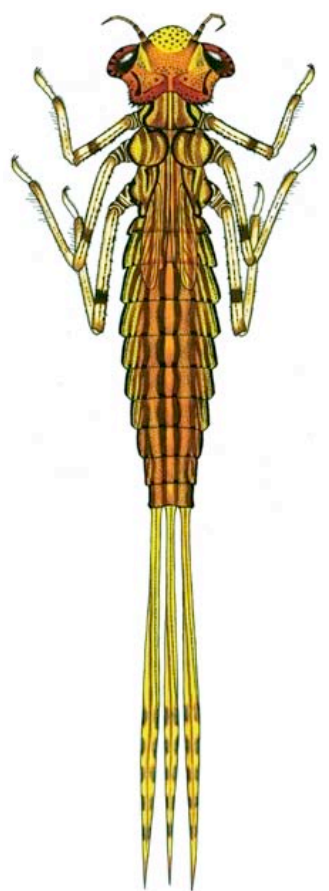

Image 7. Platycnemididae Habitat: Jagadishpur Reservoir, Lumbini, central Nepal. Length $15 \mathrm{~mm}$.

of rivers and streams in lowlands and plains. In the study area, they occurred numerously together with Coenagrionidae in submerged macrophytes of ponds, reservoirs and lakes. The general color appearance of the observed larval forms is uniform light yellow brown. The identification of genus- or species level is almost impossible due to the high number of taxa with completely unknown larvae.

\section{Platycnemididae}

The caudal gills of the larvae are very long, their length is approximately the same as the abdomen with apices somewhat pointed or attenuated and inconspicuous tracheal branching (Image 7). The gills are not usually clearly divided into proximal and distal portions. The third segment of antenna is slightly longer than the second. The anterolateral margins of the labial mentum are not toothed.

The records of larvae in the study area are rare. The family occurs at elevations ranging from about $200 \mathrm{~m}$ to $1900 \mathrm{~m}$. The figured specimen (Image 7) was found in the littoral section of Jagadishpur reservoir (197m).

\section{Coenagrionidae (Synonym: Agrionidae)}

The larvae have leaf-like caudal gills of similar shape and length. The gills are not usually distinctly divided into proximal and distal portions. The caudal gills are shorter than the abdomen, with rounded apices and conspicuous tracheal branching. The anterolateral margins of the labial mentum are not toothed and 3-5 premental setae are usually situated on either side of the midline of the mentum. The third segment of antenna is shorter than the second.

This family has the highest species number among all Zygoptera with 1,080 taxa and a worldwide distribution. Coenagrionidae (Image 8a-d) inhabit a wide range of running and stagnant waters; the most diversified fauna is found in wetlands and lentic zones of rivers and streams. In the study area, they occurred numerously together with Libellulidae in submerged macrophytes of ponds, reservoirs and lakes. The general color appearance included light yellow brown forms, dark striped forms, and bright green to dark brown forms. The distinction between Coenagrionidae and Protoneuridae is very easy based on the form of head and color but the identification of genus or species level is almost impossible due to the high number of taxa with completely unknown larvae.

\section{Anisoptera: Gomphidae}

The general body shape of Gomphidae (Image 9 $\mathrm{a}-\mathrm{b})$ is compact, and elongate with an ovate dorsoventrally flattened abdomen. The legs and often the whole larval body is covered with various types of hairs, setae, and spines. The antennae are foursegmented with the third segment enlarged. The tarsi of the first two pairs of legs are two-segmented. The labial mentum is more or less quadrate and the anterior margin of labial mentum is never cleft.

The larvae mostly inhabit running waters and are highly diversified in lowlands at floodplains of large rivers. Worldwide there are more than 966 species known. All Gomphidae are burrowers in sediment. The larvae process various morphological adaptations to different sediment types. Despite their burrowing lifestyle some Gomphidae are very good swimmers too.

The larval body of sand and silt (Psammopelal, Pelal) burrower is covered with fine hairs. Living specimens have attracting light greenish colour (Image 9a). They occur in moderately polluted water bodies. In case of fine gravel (akal) burrower, only the legs are covered with fine hairs. The third antenna segment is broadened spooned-shaped (Image 9b). Living specimens have yellow-orange brownish colour. They occur in non/slightly and moderately polluted river 

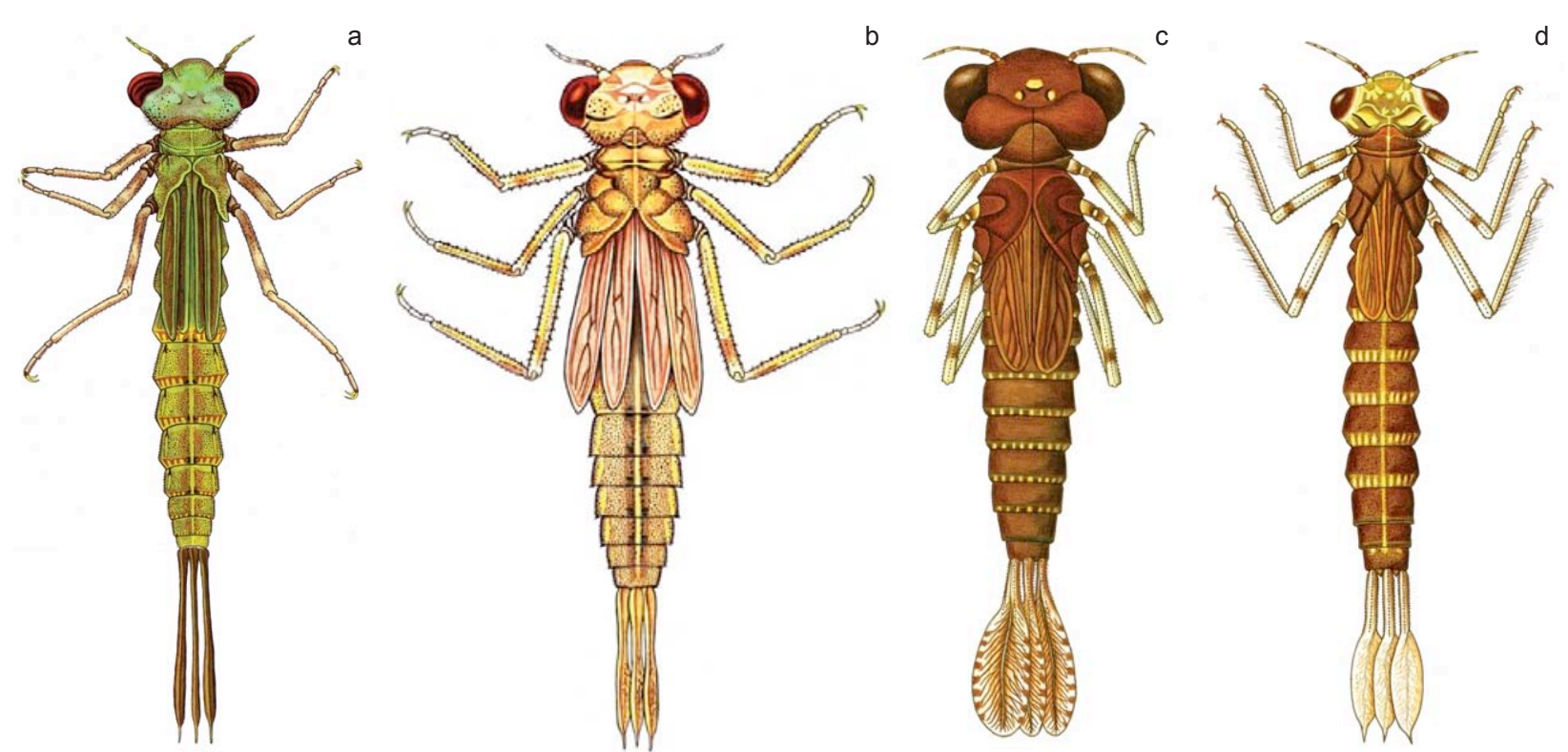

Image 8 a-d: Coenagrionidae - Habitat: a \& b - Dhobi Khola near Kathmandu University, Dhulikhel, central Nepal; c - Ghodaghodi Tal, Kailali, far western Nepal; d - Ghate Khola (Inlet of fishpond), Hetauda, central Nepal. Length: (a) $18.2 \mathrm{~mm}$; (b) $12.5 \mathrm{~mm}$; (c) $14.5 \mathrm{~mm}$; (d) $13 \mathrm{~mm}$.
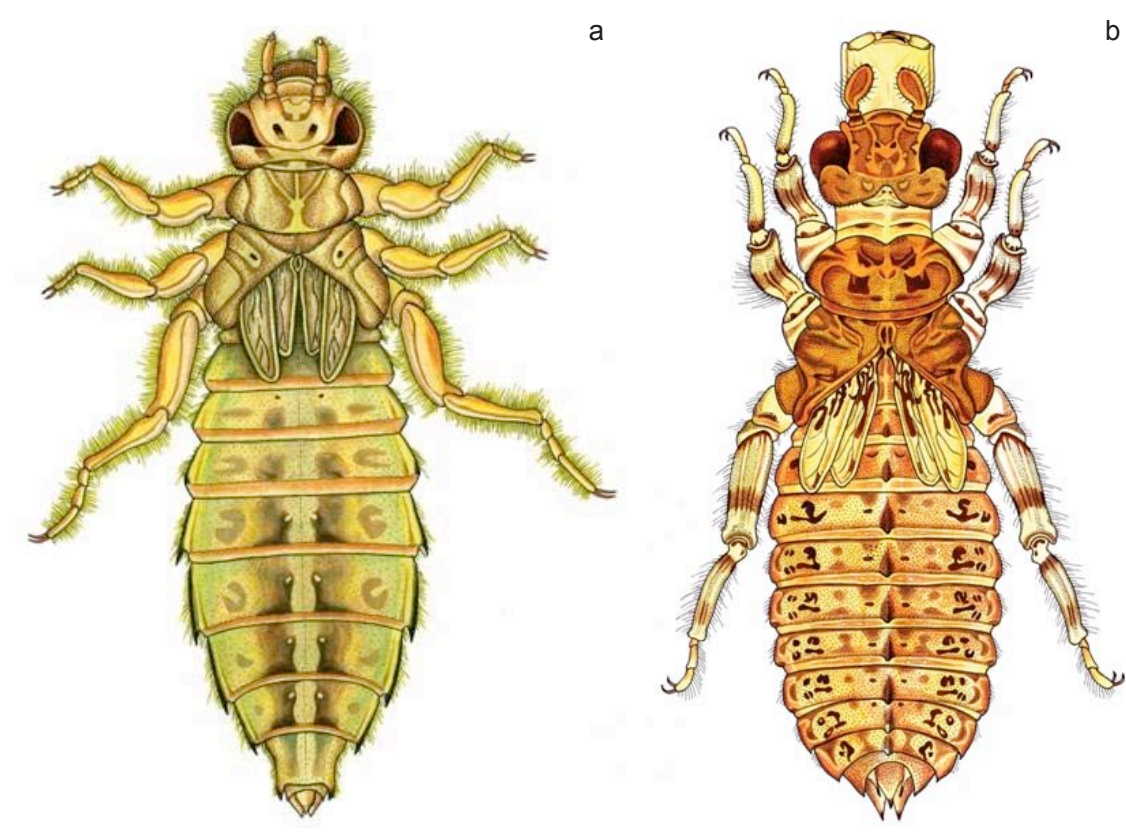

Image 9 a-b. Gomphidae - Habitat: (a) Ganga River, right bank at Ghandi Ghat, Patna (Bihar) Northern India; (b) Bijayapur Khola, Pokhara, western Nepal. Length: (a) $21 \mathrm{~mm}$; (b) $18 \mathrm{~mm}$.

stretches. The figured specimen (Image 9b) was found in the same habitat of Aphelocheirus spp. (Heteroptera: Nepomorpha: Aphelocheiridae).

\section{Lindeniinae}

This subfamily (Prasad \& Varshney 1995, p. 403) or family (Hawking \& Theischinger 1999, p. 25) (Image 10) comprises the genera Sieboldius, Ictinogomphus and Gomphidia in Asia and Australia. Kalkman et al., (2008) does not include Lindeniinae (or Lindeniidae) as a separate taxon. The larvae are very large and robust with circular flattened abdomen. Previously they were placed into the family Gomphidae, but differ in several characters and life style. The labium is enlarged and much broader than in Gomphidae. The colour of the body is dark ochre-brown.

Lindeniinae larvae are not sediment-inhabiting; they are exclusive climbers on submerged macrophytes. They colonize large stagnant water bodies and slowly running rivers from lowlands up to $800 \mathrm{~m}$. Larva 


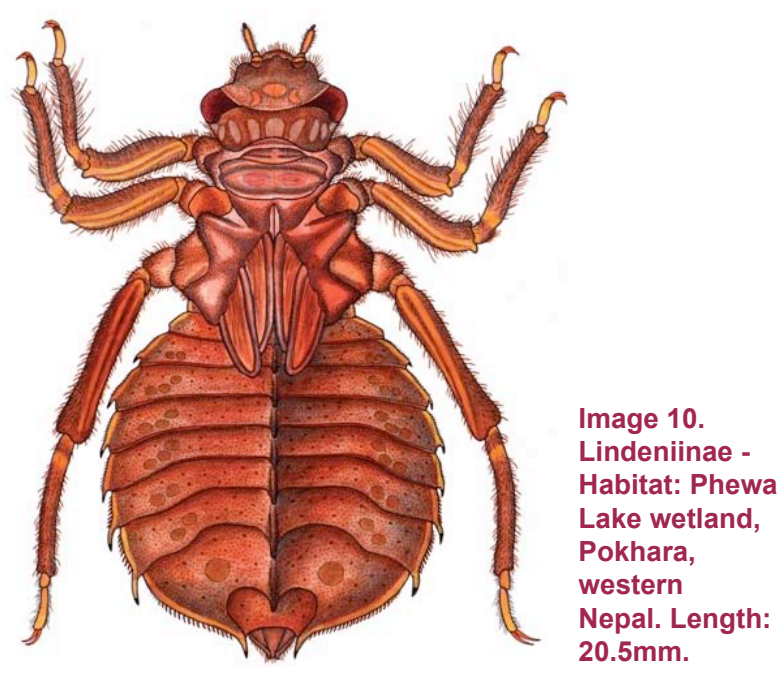

was found climbing on submerged macrophytes in a lentic zone of Metapotamon-type (large river). They were recorded in a moderately polluted water body. It is locally abundant in floating macrophytes, found in Nepal (Phewa Tal wetlands, Begnas Tal effluent) and India (Jharkhand, upper Subernarekha River and Maharashtra, Tahoba wetland), preferring Eichhornia crassipes as substrate.

Lindeniidae were already separated from the majority of Gomphidae on subfamily level as Hageniinae by several authors (St. Quentin \& Beier 1968 , p. 8). More recent publications raise them to family level (Xylander \& Günther 2003, p. 141).

\section{Aeshnidae}

Aeshnidae larvae (Image $11 \mathrm{a}-\mathrm{d}$ ) are the largest among odonata reaching more than $5 \mathrm{~cm}$ length. The larvae are rather elongated with a robust, cylindrical abdomen and very large eyes. The antennae are six or seven-segmented and filamentous. The tarsi of all legs have three segments. The labial mentum is widest in the distal portion and narrowing towards the posterior part with a cleft in the anterior margin. The body surface of the larvae is smooth, without any hairs, setae or bristles. The larval colour display a wide range from light yellow, bright green, ochre brown to dark brownish often with segmentally arranged dark patterns on the dorsal side of the abdomen.

Within the family Aeshnidae, the subfamily Anactinae is mainly confined to the Ethiopian and Oriental regions with range extension of some species into the temperate Palearctic. In the Indian subcontinent, they are found sporadically in various undisturbed, natural, slightly and moderately polluted waters. They are nowhere abundant or common and only small numbers of individuals were observed.

\section{Cordulegastridae}

The body of Cordulegastridae larvae (Image 12) is elongate and covered with bristles or tufts of setae. The distal margin of the palpal lobes of labium is with large irregular teeth which interlock with those on the corresponding lobe. The anterior margin of the mentum is cleft. The colour appearance is dominated
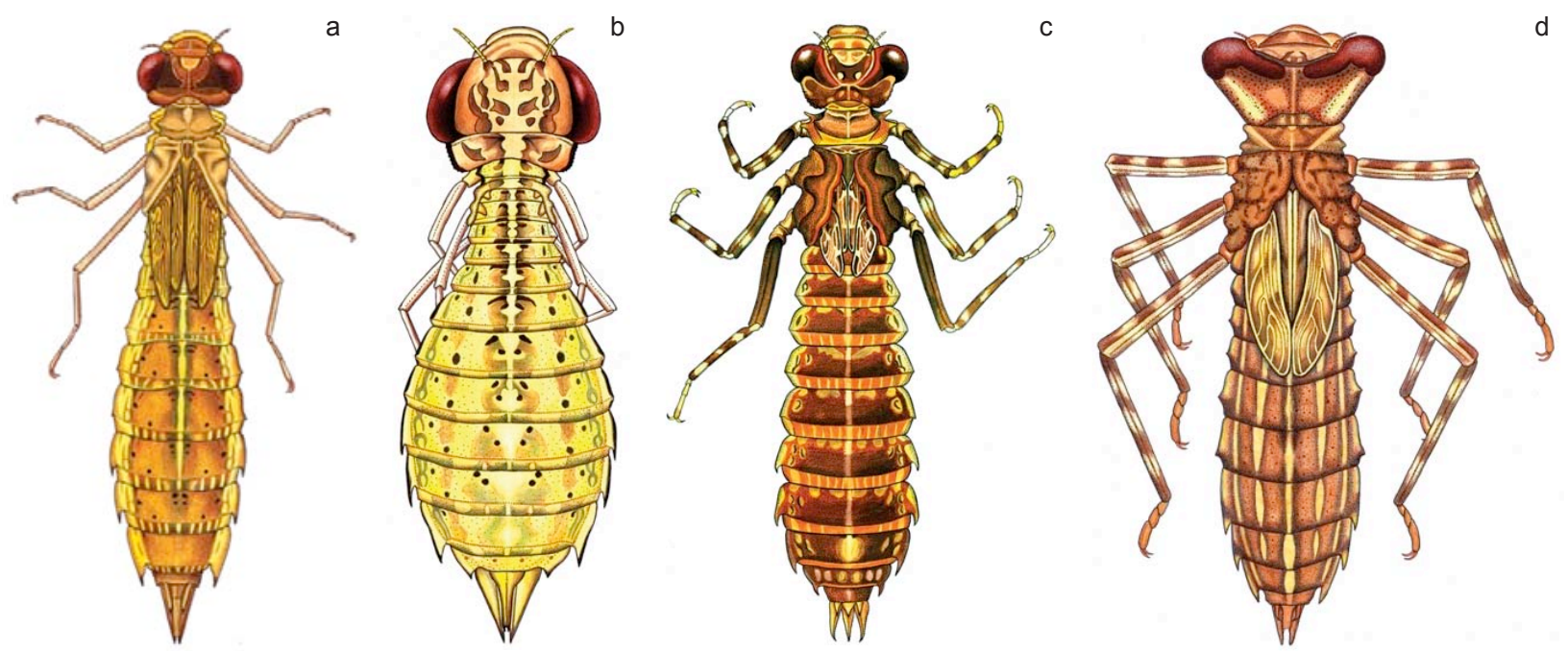

Image 11 a-d. Aeshnidae - Habitat: a - Gaur municipality pond, Rautahat, central Nepal; b - Punpun River, Gaurichak, Patna, northern India; c - Khimti Khola, central Nepal; d - Punyamata Khola, Nagarkot hill, central Nepal. Length (a) $53 \mathrm{~mm}$; (b) $10.3 \mathrm{~mm}$; (c) $30.5 \mathrm{~mm}$; (d) $26.5 \mathrm{~mm}$ 


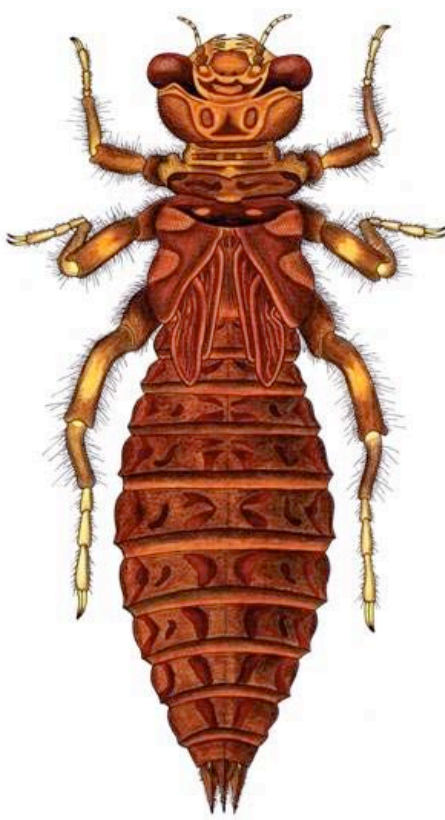

Image 12.

Cordulegastridae -

Habitat: Pengul Khola,

Sindhupalanchwok,

central Nepal.

Length: $33.5 \mathrm{~mm}$.

by a dark brown background with some blackish markings, regularly arranged on the dorsal side of the abdominal segments.

The family has a limited distribution range in the Palearctic and Oriental regions. The larvae are crawlers on sand and muddy sediments of fast running cool streams and rivers, especially in the Himalaya. They usually lay half buried in the surface sediment layer and wait for prey. The larvae are pollutionsensitive and demand highly oxygenated water. They are not common and were recorded during the present study only from the upper stretches of small rivers and streams of natural forests above $1500 \mathrm{~m}$.

\section{Macromiidae}

The legs of Macromiidae (Image 13) are very long, giving the larvae a "spidery" appearance. The abdomen is depressed and more or less circular in outline. On the head, a small "horn" is present between the antennal bases. The labium bears rather long, regular teeth along the distal margins of the palpal lobes.

The family has a worldwide distribution but their occurrence is restricted in the tropical, subtropical and warm temperate zones except South America. There are approximately 120 species known. They prefer running water with low organic input and are found in slightly to moderately polluted stretches. A few Macromia and Epophthalmia species are recorded from northern India and Nepal (Sharma 1998; Mitra

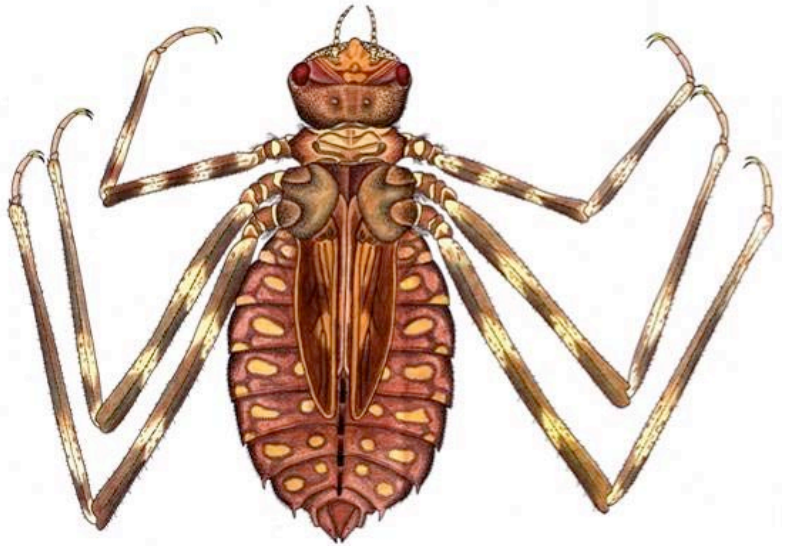

Image 13. Macromiidae - Habitat: Mahadev Khola, Bhaktapur, central Nepal. Length: $23.5 \mathrm{~mm}$.

2003). The Macromiidae are recently raised to family level, previously they were placed as subfamily Epophthalmiinae into family Corduliidae.

They are frequently recorded from the upper regions of undisturbed forest streams in the Himalayan middle mountains from 800 to $1970 \mathrm{~m}$. The figured specimen might belong to Macromia moorei moorei, which is spread widely over the northern Indian subcontinent. The larvae occur on coarse-grained sand or gravel substrate (Psammal, Akal) deposited behind or under large stones.

\section{Corduliidae}

The larvae of Corduliidae (Image $14 \mathrm{a}-\mathrm{b}$ ) resemble Libellulidae, but their size is usually larger and the body is more firm than the latter ones. Their legs are rather short and the apex of the femur does not extend beyond abdominal segment VIII. The abdomen is not markedly depressed or circular in outline. The cerci are generally more than one-half as long as paraprocts.

The total number of species is 255 worldwide; in Asia the family is less represented. Historically, there was no clear distinction between the three families Libellulidae, Corduliidae and Macromiidae. They all were placed into a single family Libellulidae. More recently fundamental characters of the anal pyramid allow distinguishing larvae. In Corduliidae, the length of cerci exceeds always more than half as long as epiproct, whereas in Libellulidae the length of cerci is less than half as long as epiproct (Okudaira et al. 2005 , p. 360). They were rarely collected in the study area from slowly running stretches of stream and river 


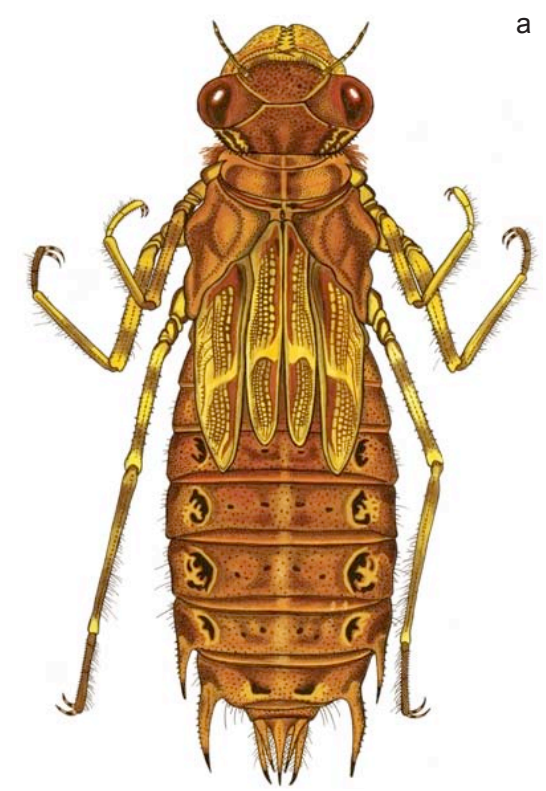

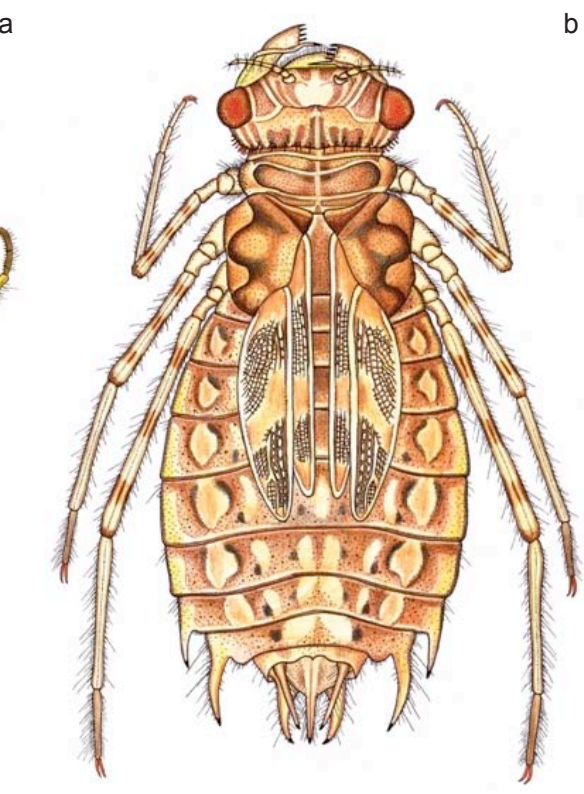

Image 14 a-b: Corduliidae - Habitat: a - Dhobi Khola near Kathmandu University, Dhulikhel, central Nepal; b - Ghate Khola (Inlet of fishpond), Hetauda, central Nepal.

Length: (a) $26.3 \mathrm{~mm}$; (b) $22 \mathrm{~mm}$. with moderate to heavy pollution. It is not possible to recognize and separate them in the field from Libellulidae; proper identification can be only done in a laboratory with a microscope.

\section{Libellulidae}

The larvae (Image $15 \mathrm{a}-\mathrm{g}$ ) are minute to mediumsized and have a delicate comparatively soft body. Their legs are rather short and the apex of the femur does not extend beyond abdominal segment VIII. The abdomen is not markedly depressed or circular in outline. The cerci generally are not more than onehalf as long as paraprocts.

The family Libellulidae, the largest family of Anisoptera has a cosmopolitan distribution with more than 970-1,012 described species. The larvae are very similar in appearance and shape to Corduliidae but differ by their anal pyramid. In Libellulidae, the length of the cerci is less than half as long as epiproct. Body colour of the different species may cover a wide range from bright yellow, light greenish to dark brown. Larvae are usually very abundant in all types of stagnant waters and are able to colonize successfully even in small water bodies with low oxygen where other odonates cannot survive.

\section{Anisozygoptera: Epiophlebiidae}

The larvae are somewhat slender and elongate; with a slight petiolation at the base of the wing pad. The minute and very short antennae are with five segments. The larval body is very hard and firm covered with tubercles, but lacking any bristles. The family is extremely rare with isolated discontinuous relict distribution in Japan and the Himalaya only. The family is certainly recorded from Mesozoic onwards (Nel \& Jarzembowski 1996).

There are only two extant species, regarded as 'living fossils'. Epiophlebia superstes are recorded only from Japan while Epiophlebia laidlawi are recorded from the Himalayan regions of Bhutan, India and Nepal. The life cycle of the Epiophlebia superstes is better known, including adults, terrestrial phase, and egg deposition; adults of E. laidlawi are not yet found. The larvae are limited on natural upper regions of fast running forest streams with good water quality. Small larvae prefer rapids and riffles with embedded stream bottom; they are highly pollution-sensitive and live only in Epirhithron- to Metarhithron-type of biocoenotic zone (Nesemann et al. 2008, 2011).

The young larvae (Image 16a) differ markedly in dorsal colour, having dark pigmentation only on abdominal segments 2 to 5 , and 9. Large larvae have generally brownish or nearly blackish appearance with dorsal metameric pattern on abdomen (Image 16b). The distinguishing of male and female individuals by the presence of ovipositor is only possible for larger larvae from $8 \mathrm{~mm}$ body length onwards (Nesemann et al. 2008, 2011). 

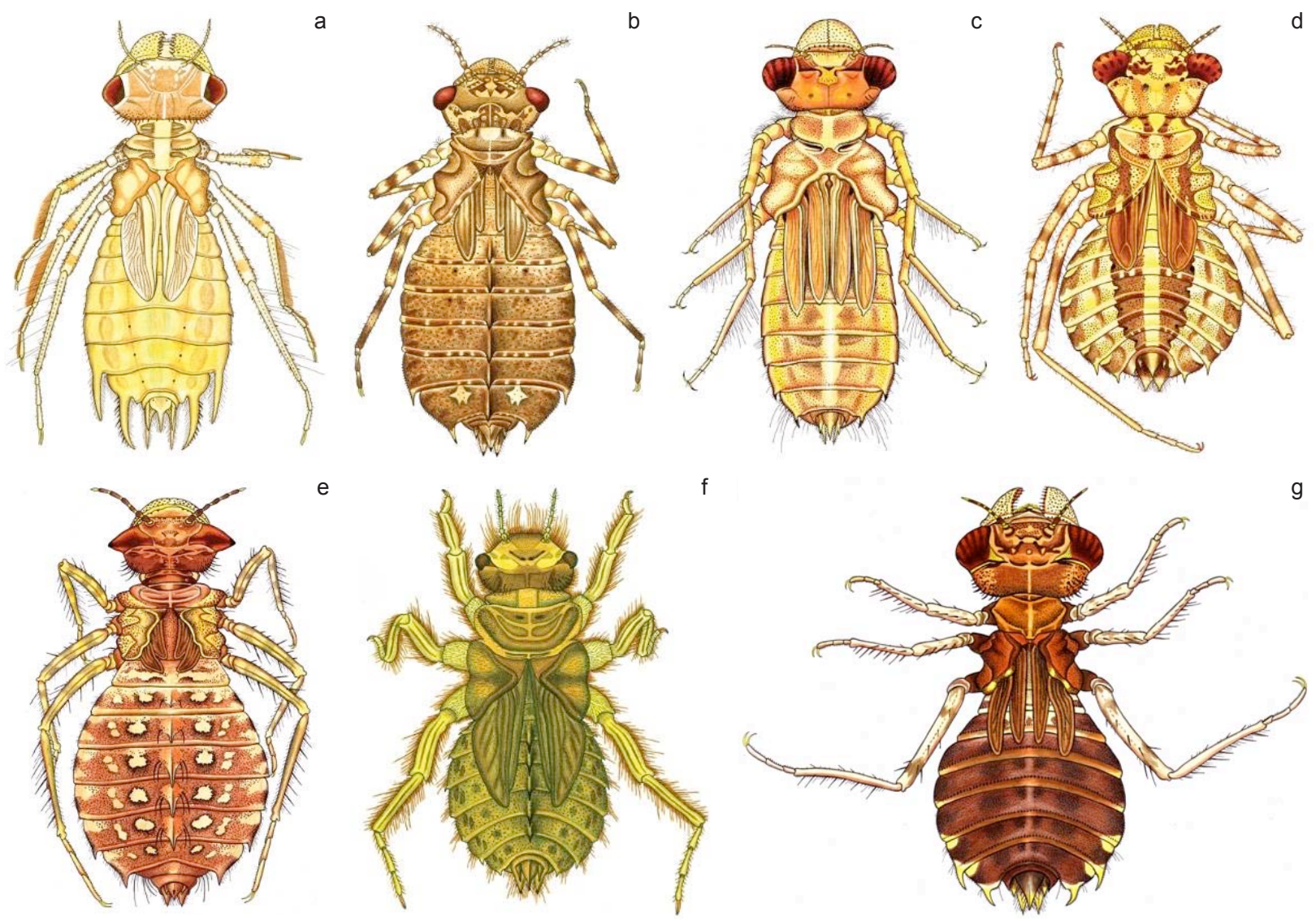

Image 15 a-g. Libellulidae - Habitat: a - Cha Khola (irrigation channel), Kuntabesi, central Nepal; b - Nagdaha pond, Lalitpur, central Nepal; c - Kumhrar park, "Bivalvia" pond, Patna, northern India; d - Taudaha Lake, Kirtipur, central Nepal; e - Kumhrar park, "Phoenix" pond, Patna, northern India; f \& g - spring pools in Kathmandu University, Dhulikhel, central Nepal. Length (a) $24 \mathrm{~mm}$; (b) $11.5 \mathrm{~mm}$; (c) $12.2 \mathrm{~mm}$; (d) $12.5 \mathrm{~mm}$; (e) $13.8 \mathrm{~mm}$; (f) $18 \mathrm{~mm}$; (g) $18 \mathrm{~mm}$.
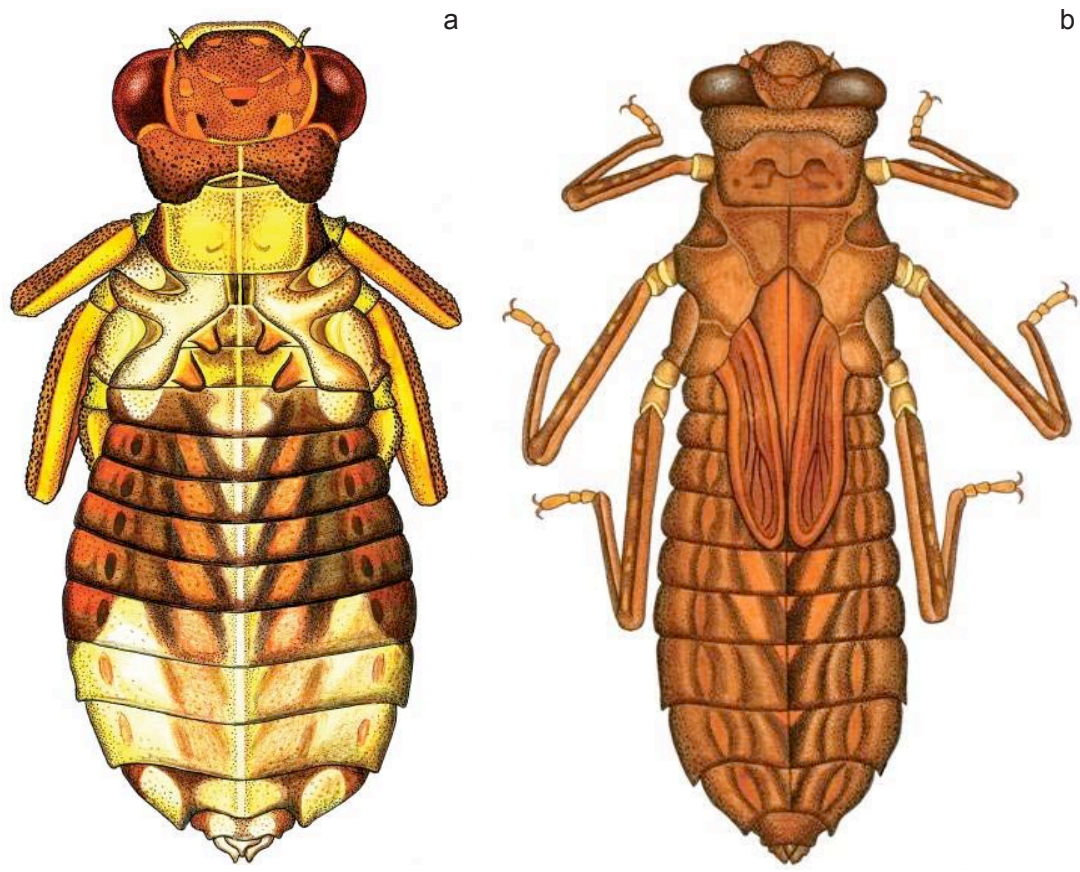

Image 16 a-b. Epiophlebiidae (Epiophlebia laidlawi) - Habitat: a - Sim; b - Simbhanjyang Khola, Daman, central Nepal. Length: (a) $8.6 \mathrm{~mm}$; (b) $23 \mathrm{~mm}$. 


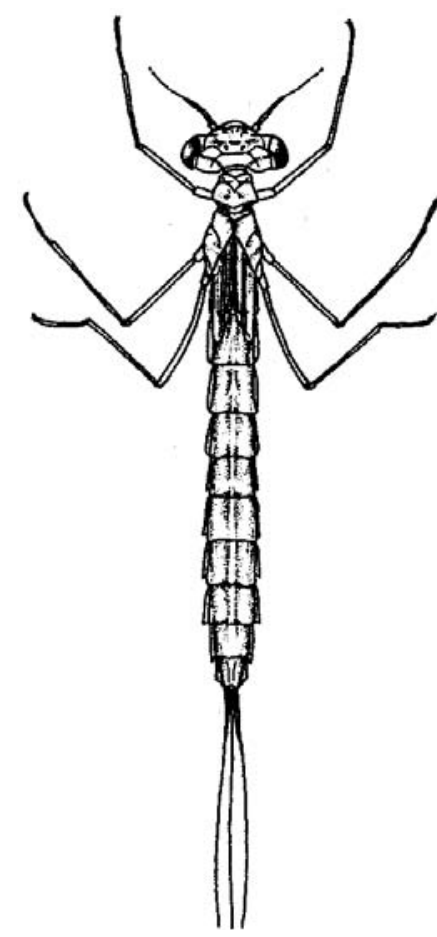

Figure 7. Lestidae [fig. taken: Kawai 1985: 62 (fig. no. 3a), Lestes sp. (length unknown)]

\section{TAXONOMIC KEY}

The order Odonata can be divided into two distinct groups or suborders: Damselflies (Zygoptera) and Dragonflies (Anisoptera).

Damselflies larvae are usually more slender than dragonflies and their abdomen terminates in three caudal filaments (gills) resembling leaves. Dragonflies larvae are much more robust with an abdomen terminating in five points consisting of a pair of cerci, a pair of paraprocts, and a single epiproct. In both damselflies and dragonflies, the shape of the lower lip (labium) can be a diagnostic character for separating families. The shape of antennal segments is also an important character in identification of odonates.

\section{REFERENCES}

Balian, E.V., H. Segers, C. Le'v`eque \& K. Martens (2008). The freshwater animal diversity assessment: an overview of the results. Hydrobiologia 595: 627-637.

Brockhaus, T. \& A. Hartmann (2009). New records of Epiophlebia laidlawi Tillyard in Bhutan, with notes on its biology, ecology, distribution, zoogeography and threat status (Anisozygoptera: Epiophlebiidae). Odonatologica 38(3): 203-215.

Dudgeon, D. (1999). Tropical Asian Streams: Zoobenthos, Ecology and Conservation. Hong Kong University Press, HKU, 291-316pp.

Fraser, F.C. (1919a).The larva of Micromerus lineatus Burm. Records of the Indian Museum 16: 197-198+Pls 23.

Fraser, F.C. (1919b). Descriptions of New Indian Odonate Larvae and Exuviae. Records of the Indian Museum 16: 459-467+Pls 32-37.

Hawking, J. \& G. Theischinger (1999). Dragonfly Larvae (Odonata): A Guide to The Identification of Larvae of Australian Families and to the Identification and Ecology of Larvae from New South Wales. Identification guide (Cooperative Research Centre for Freshwater Ecology (Australia) No. 24, New South Wales, 240pp.

Hassall, C. \& D.J. Thompson (2008). The effects of environmental warming on Odonata: a review. International Journal of Odonatology 11(2): 131-153.

Kalkman V.J., V. Clausnitzer, K.D.B. Dijkstra, A.G. Orr, D.R. Paulson \& J. van Tol (2008). Global diversity of dragonflies (Odonata) in freshwater. Hydrobiologia 595: 351-363.

Kalkman V.J., Choong, C.Y,, A.G Orr \& K. Schütte (2010). Remarks on the taxonomy of Megapodagrionidae with emphasis on the larval gills (Odonata). International Journal of Odonatology 13: 119-135.

Kawai, T. (ed.) (1985). An Illustrated Book of Aquatic Insects of Japan. Tokai University Press, Tokyo, viii $+409 \mathrm{pp}$ (Reprint from 2001).

Kawai, T. \& K. Tanida (2005). Aquatic Insects of Japan: Manual with Keys and Illustrations. Tokai University Press, Tokyo, 1342pp.

Kemp, K.G. \& S.G. Butler (2001). Some Dragonfly records from Phewa Tal, Pokhara, Nepal with notes on Philoganga

\section{Key to Odonata suborders}

1. Larvae slender, head wider than thorax and abdomen; abdomen terminating in three long caudal leaf-or sac-like gills (these gills are fragile and are sometimes broken off and lost)... Zygoptera (Damselflies)

2. Abdomen rather short and stout, lacking caudal gills; head usually narrower than thorax and abdomen; five short stiff, pointed appendages at tip of abdomen ending in five points; the three largest of which form an 'anal pyramid' Anisoptera (Dragonflies)

3. Larvae stout, elongate with a slight petiolation at the base of the wing pad; antennae with five segments; body covered with tubercles, but lacking bristles, body firm; extremely rare and restricted in the Himalayas (Nepal, India and Bhutan)....................................................Anisozygoptera (Relict Dragonflies): one family with one species: Epiophlebiidae (Epiophlebia laidlawi) (Image 16 a\&b) 


\section{Key to Zygoptera Families}

1. Two forceps-like caudal gills (the median gill is minute) which are triangular in cross section............... Chlorocyphidae (Fig. 6)

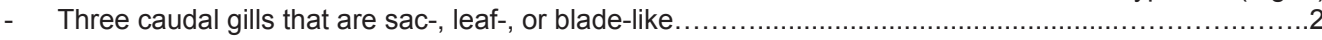

2. Filamentous gills on the underside of abdominal segments II-VIII Euphaeidae (Image $1 \mathrm{a}-\mathrm{b})$

No filamentous gills on the underside of abdominal segments II-VIII

3. First antennal segment longer than the combined length of subsequent segments; anterior margin has a well-developed median cleft .................................................................. Calopterygidae (Image 2)

- First antennal segment much shorter than the combined length of subsequent segments.................4

4. Labium distinctly spoon-shaped and strongly tapered posteriorly .........................estidae (Fig. 7)

- Labium quadrate or more or less triangular in shape, with palpal lobes bearing moveable hooks or spines at the tips, and lacks setae on the mentum or palpal lobes...............................................

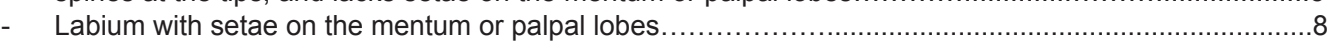

5. Gills leaf-like with rounded apices. Synlestidae (Image 3)

Gills more or less saccoid...

6. Delicate aquatic larvae with flattened bodies and relatively long antennae; long, slender legs fringed

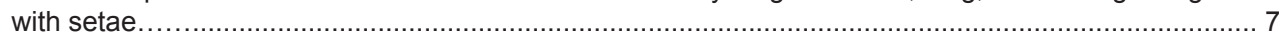

7. Larvae may be large and deeply pigmented; palpal lobes of the labium with three spines and one movable hook ...........................................Amphipterygidae (including: Philogangidae) (Image 4) Pale, somewhat spindly larvae with large bulbous eyes; palpal lobes of the labium with a single spine and one movable hook .............................................................................. Platystictidae (Image 5)

8. Gills clearly divided into a thickened dark proximal portion and a thin, paler distal part; one premental seta is situated on either side of the midline of the mentum; anterolateral margins of the labial mentum

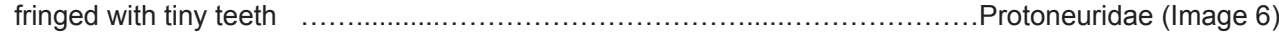

- Gills not usually clearly divided into proximal and distal portions; anterolateral margins of the labial mentum are not toothed; usually more than one premental seta on either side of the midline of the mentum.

9. Caudal gills long (approximately the same length as the abdomen); third segment of antenna longer than the second ............................................................................ Platycnemididae (Image 7)

- Caudal gills shorter than the abdomen; third segment of antenna shorter than the second; 3-5 premental setae are usually situated on either side of the midline of the mentum.

Coenagrionidae (Image 8 a-d)

\section{Key to Anisoptera Families}

1. Labial mentum or palpal lobes more or less flat; without setae on the mentum or (usually) the palpal lobes ......................................................................................................................... 2

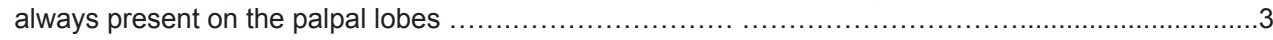

2. Antennae four-segmented, with the 3rd segment enlarged; tarsi of the first two pairs of legs are twosegmented; labial mentum more or less quadrate; anterior margin of labial mentum is never cleft,

A. With elongated abdomen, burrowing in substrate Gomphidae (Image 9 a-b)

B. With circular and widened abdomen, climbing on macrophytes......................... Lindeniinae (Image 10)

- Antennae six or seven-segmented and filamentous; tarsi of all legs have three segments; labial mentum widest in the distal portion and narrowing towards the posterior with a cleft in the anterior margin........

Aeshnidae (Image $11 \mathrm{a}-\mathrm{d}$ )

3. Body elongate and covered with bristles or tufts of setae; distal margin of the palpal lobes of the labium with large irregular teeth; anterior margin of the mentum is cleft......Cordulegastridae (Image 12)

Body short and stout; anterior margin of the mentum is cleft.

4. Legs very long giving the larvae a 'spidery' appearance; abdomen depressed and more or less circular in outline; a small 'horn' may be present between the antennal bases................ Macromiidae (Image 13)

- Legs rather short; abdomen not markedly depressed or circular in outline

5. Cerci generally more than one-half as long as paraprocts

Cerci generally not more than one-half as long as paraprocts

Montana (Selys) (Zygoptera: Amphipterygidae). Notulae Odonatologicae 5(7): 85-96.

Kumar, A. \& M. Prasad (1977). On the larvae of Rhinocypha (Odonata: Cholorocyphidae) from Garhwal hills. Oriental Insects 11(4): 547-554.
Malz, H. \& H. Schröder (1979). Fossile Libellen - biologisch betrachtet. - Kleine Senckenberg-Reihe Nr. 9: 1-46 (Fossil Dragonflies - Biological view [in German]).

Mitra, T.R. (2003). Ecology and biogeography of Odonata with special reference to Indian Fauna. Records of the 
Zoological Survey of India, Occasional Paper No. 202: 1-41+Plate 1-4

Mitra, A. (2005): Life history pattern and larval development of Neurothemis fulvia Drury (Odonata: Libellulidae) from Dehra Dun valley, India: A comparative analysis with two other species of the genus. Annals of Forestry 13(2): 311322.

Mitra, A. (2006). Current status of the Odonata of Bhutan: A checklist with four new records. The Journal of Renewable Natural Resources Bhutan 2(1): 136-143.

Nesemann, H., R.D.T. Shah, D.N. Shah \& S. Sharma (2008). Morphological development of Epiophlebia laidlawi, a relict Himalayan Dragonfly. Abst. Paper in Proceeding of 18th International Symposium of Odonatology Nagpur, 43pp.

Nesemann, H. (2009). Aquatic benthic macroinvertebrates' biological diversity and their use in habitat quality assessment at the Himalayan hot spots of Ganges River Basin. PhD Thesis. Kathmandu University, xv+204pp.

Nesemann, H., R.D.T. Shah, D.N. Shah \& S. Sharma (2011). Morphological characters of Epiophlebia laidlawi Tillyard larvae, with notes on the habitat and distribution of the species in Nepal ("Anisozygoptera": Epiophlebiidae). Odonatologica 40: 191-202.

Ofenböck, T., O. Moog, S. Sharma \& T. Korte (2010). Development of the HKHbios: a new biotic score to assess the river quality in the Hindu Kush-Himalaya. Hydrobiologia 651(1): 39-58.

Okudaira, M., M. Sugimura, S. Ishida, K. Kojima, K. Ishida, \& T. Aoki (2005). Dragonflies of the Japanese Archipelago in Color. Hokkaido University Press, 593pp.

Shah, D.N. (2007). Ecological and water quality status of river and irrigation channels of lower gangatic plains moist deciduous forest of Nepal. MSc Thesis. Tribhuvan University. xiii+71pp.

Sharma, S. (1998). An inventory of the aquatic insects of Nepal used as bio-indicators of water pollution. A report to the secretariat of the university grants commission, Kathmandu, Nepal.

St. Quentin, D. \& M. Beier (1968). Odonata (Libellen). In: Beier, M. (ed.): "Handbuch der Zoologie". Eine Naturgeschichte der Stämme des Tierreiches. IV. Band: Arthropoda - 2. Hälfte: Insecta, 2. Teil: Spezielles 4(2): $1-39$.

Subramanian, K.A. (2009) A Checklist of Odonata (Insecta) of India. Zoological Survey of India Western Regional Station, Pune-411 044 Maharashtra, India, December 2009, Ebook, pp. 1-38 zsi.gov.in/checklist/Odonata_Indica_151209.pdf. Downloaded on 20 December 2010.

Tachamo, R.D. (2007). Ecological and Water Quality Status of Middle Hill Rivers of Central Nepal. MSc Thesis. Tribhuvan University. xiii +72 .

Tachamo, R.D. (2010). Identifying key environmental variables structuring benthic macroinvertebrates for stream typology of Indrawati River System, Nepal. MSc Thesis. UnescoInstitute for Water Education, xiii+60pp

Trueman, J.W.H. \& R.J. Rowe (2001). Odonata. Dragonflies and damselflies. $<\mathrm{http}$ //tolweb.org/ Odonata/8266/2001.01.01> On-line version dated 01 January 2010.

van Tol, J. (2008). Catalogue of the Odonata of the World. National Museum of Natural History (Naturalis), Leiden. The Netherlands. < http://www.odonata.info $>$. On-line version dated 03 January 2010.

Vick, G.S. (1989). List of the Dragonflies recorded from Nepal, with a summary of their altitudinal distribution (Odonata). Opuscula Zoologica Fluminensia 43: 1-21.

Xylander, W.E.R. \& K.K. Günther (2003). Ordnung Odonata, Libellen. - In: Dathe, H.H. (ed.): Lehrbuch der Speziellen Zoologie. Band 1: Wirbellose Tiere. 5. Teil: Insecta, 121142pp.

Yule, C.M.\& H.S. Yong (eds.) (2004). Freshwater Invertebrates of the Malayasian Region. Academy of sciences, Malaysia, Vii+861pp. 